\title{
Lactation curves and economic results of Saanen goats fed increasing dietary energy levels obtained by the addition of calcium salts of fatty acids ${ }^{1}$
}

\section{Rodrigo de Souza ${ }^{2}$, Claudete Regina Alcalde ${ }^{2}$, Carlos Antonio Lopes de Oliveira ${ }^{2}$, Bruna Susan de Labio Molina², Francisco de Assis Fonseca de Macedo², Ludmila Couto Gomes², Bruna Hygino ${ }^{2}$, Ana Paula Silva Possamai ${ }^{2}$}

\footnotetext{
${ }^{1}$ Research financed by Conselho Nacional de Desenvolvimento Cientifico e Tecnológico - Edital MCT/CNPq n 014/2010 - Universal.

${ }^{2}$ Departamento de Zootecnia, Universidade Estadual de Maringá, Maringá, PR, Brasil.
}

\begin{abstract}
The objective of this study was to evaluate the use of calcium salts of fatty acids (CSFA) to increase the dietary energy levels for Saanen goats and their effects on the lactation curve, dry matter intake, body weight, and economic results of the goats. Twenty multiparous goats, weighing an average of $63.5 \pm 10.3 \mathrm{~kg}$, were randomly assigned to one of four treatment groups, each receiving one of the following dietary energy levels: a control diet consisting of 2.6 Mcal of metabolizable energy per $\mathrm{kg}$ of dry matter (Mcal ME/kg DM) or a test diet supplemented with CSFA (Lactoplus ${ }^{\circledR}$ ) to obtain 2.7, 2.8, or 2.9 Mcal ME/kg DM. Goats were housed in individual stalls and were fed and milked twice daily. The animals were evaluated until 180 days in milk by measuring dry matter intake and milk yield. These measurements were used to calculate feed efficiencies and the cost-benefit ratio of diet and lactation curves using Wood's nonlinear model. Increasing dietary energy levels showed no effect on body weight. Supplementation with CSFA did not limit dry matter intake; however, it changed the shape of the lactation curve by promoting a late peak lactation with a longer duration. Milk yields at 180 days in milk had a quadratic increase with a maximum energy level at $2.85 \mathrm{Mcal} \mathrm{ME} / \mathrm{kg}$ DM. Increasing the dietary energy level for Saanen goats using CSFA changes their lactation curves, with the best milk production achieved with a $2.85 \mathrm{Mcal} \mathrm{ME} / \mathrm{kg}$ DM diet; however, the greatest economic results were obtained with a $2.7 \mathrm{Mcal} \mathrm{ME} / \mathrm{kg}$ DM diet.
\end{abstract}

Key Words: calcium soap, dry matter intake, energy intake, lactation persistence, Lactoplus ${ }^{\circledR}$, peak lactation

\section{Introduction}

Great amounts of energy are required by high-yielding goats during early lactation when the feed intake capacity is limited, leading the animals to mobilize their body energy reserves (Teh et al., 1994). Thus, it is important to provide lactating goats with palatable feed containing a high energy density (Ribeiro, 1997).

One way to increase the efficiency of energy use without increasing the addition of concentrate in the diet or compromising fiber digestibility, is to supplement animals with protected fat in the form of calcium salts of fatty acids (CSFA), which allows a higher level of dietary lipids with minimal interference in rumen environment (Teh et al., 1994; Palmquist and Mattos, 2011). However, interactions among lipid supplementation, mobilization of body reserves and milk yield are not yet completely understood (Chilliard et al., 2003).

There are controversial research results regarding the use of CSFA in dairy goats. According to Sanz Sampelayo et al. (2002a), there were problems on palatability, and Sanz
Sampelayo et al. (2002b) observed no effect on milk yield in CSFA-supplemented animals. Teh et al. (1994) observed weight loss and a reduction in milk yield with CSFA supplementation, while Hosam (2011) observed an increase in milk yield in CSFA-supplemented animals, but only with the highest energy level of supplementation $(50 \mathrm{~g} / \mathrm{kg})$.

Thus, it is important to study the effects of CSFA supplementation levels on body reserve mobilization, dry matter intake and lactation curves to define strategies for the nutritional management of goats.

However, in addition to evaluating responses in milk production, it is also important to consider the economic consequences of dietary changes. Menezes (2008) noted that the success of animal production is an association between economic and productive efficiencies, suggesting that efficiency does not always mean maximum productivity.

Therefore, the objective of this study was to evaluate the use of calcium salts of fatty acids to increase the dietary energy levels for Saanen goats and their effects on the lactation curve, dry matter intake, body weight, and economic results of the goats. 


\section{Material and Methods}

Twenty multiparous Saanen goats, weighing an average of $63.5 \pm 10.3 \mathrm{~kg}$, were randomly assigned to one of four experimental groups that received diets with increasing energy levels obtained by the addition of calcium salts of fatty acids (CSFA) (Table 1).

The control diet had 2.6 Mcal of metabolizable energy per $\mathrm{kg}$ of dry matter (Mcal ME/kg DM), which was formulated according to the NRC (2007) requirements for Saanen goats with $60 \mathrm{~kg}$ of body weight (BW) producing $3.0 \mathrm{~kg}$ of milk daily. For the other treatment groups, fat was added in the form of calcium salts of long-chain fatty acids from a commercially available product derived from soybean oil (Lactoplus ${ }^{\circledR}$ from Dalquim Chemical Industry Ltd.) to increase the dietary energy and to obtain the following dietary energy levels: $2.7,2.8$ or 2.9 Mcal $\mathrm{ME} / \mathrm{kg} \mathrm{DM}$.

The trial period lasted from 21 days pre-calving through 180 days in milk and was preceded by a 14-day acclimation period. Animals were housed in individual stalls with ad libitum water and access to a solarium in the mornings for two hours.

Goats were fed at $09.30 \mathrm{~h}$ and $14.30 \mathrm{~h}$. Feed intake and orts were measured daily, and feed intake was adjusted weekly to provide approximately $10 \%$ orts.

Table 1 - Ingredients and chemical composition of experimental diets

\begin{tabular}{|c|c|c|c|c|}
\hline \multirow{2}{*}{ Item (g/kg DM) } & \multicolumn{4}{|c|}{ Diets (Mcal ME/kg DM) } \\
\hline & 2.6 & 2.7 & 2.8 & 2.9 \\
\hline Corn silage & 574.8 & 600.0 & 600.0 & 600.0 \\
\hline Ground corn & 244.4 & 185.7 & 154.1 & 122.6 \\
\hline Soybean meal & 172.6 & 179.5 & 184.9 & 190.2 \\
\hline Lactoplus ${ }^{\circledR} 1$ & - & 28.7 & 54.6 & 80.5 \\
\hline Limestone & 1.2 & - & - & - \\
\hline Dicalcium phosphate & - & 1.1 & 1.3 & 1.6 \\
\hline Mineral and vitamin supplement ${ }^{2}$ & 7.0 & 5.0 & 5.0 & 5.0 \\
\hline Dry matter ${ }^{3}$ & 528.6 & 513.7 & 517.2 & 518.1 \\
\hline Organic matter & 951.6 & 949.5 & 944.7 & 941.8 \\
\hline Crude protein & 156.9 & 158.8 & 160.6 & 164.4 \\
\hline Ether extract ${ }^{4}$ & 28.2 & 26.5 & 25.5 & 24.6 \\
\hline Supplemental fat ${ }^{5}$ & - & 23.6 & 44.8 & 66.0 \\
\hline Neutral detergent fiber & 349.8 & 359.4 & 344.9 & 341.7 \\
\hline Nonstructural carbohydrates & 416.8 & 381.3 & 368.8 & 344.9 \\
\hline Total carbohydrates & 766.6 & 740.7 & 713.7 & 686.7 \\
\hline
\end{tabular}

${ }^{1}$ Calcium salts of fatty acids.

${ }^{2}$ Chemical composition (per kg of product): vitamin A - 135,000.00 IU; vitamin D3 $68,000.00 \mathrm{IU}$; vitamin E - $450 \mathrm{IU}$; Ca - 240.00g; P - 71.00g; K - $28.20 \mathrm{~g}$; S - $20.00 \mathrm{~g}$; $\mathrm{Mg}$ - $20.00 \mathrm{~g} ; \mathrm{Cu}-400.00 \mathrm{mg}$; Co - $30.00 \mathrm{mg}$; Cr - $10.00 \mathrm{mg} ; \mathrm{Fe}-2,500 \mathrm{mg}$; I $40.00 \mathrm{mg}$; Mn - 1,350.00 mg; Se - $15.00 \mathrm{mg}$; Zn - 1,700.00 mg; F - $710.00 \mathrm{mg}(\max )$; Citric acid $2 \%$ (min) solubility of phosphorus $95 \%$ ( $\mathrm{min}$ ) - commercial product.

${ }^{3} \mathrm{~g} / \mathrm{kg}$ fresh weight.

${ }^{4}$ Obtained by results of analysis of corn silage, ground corn and soybean meal.

${ }^{5}$ Information from the manual of the manufacturer, Lactoplus ${ }^{\circledR}$ (Dalquim Chemical Industry Ltd.).
Goats were bred by the same Saanen buck on natural breeding. Pregnancy duration was recorded, and the goats and kids were weighed after calving to evaluate the effect of diets during the gestation period.

Milking was done twice daily, at $07.30 \mathrm{~h}$ and $15.00 \mathrm{~h}$, followed by milk weighing. To obtain a fat-corrected milk yield, milk samples of equal volumes were collected monthly from each animal during both daily milkings. These milk samples were packed in plastic bottles containing Bronopol $^{\circledR}$ (2-bromo-2-nitropropane-1,3-diol). A Bentley $2000^{\circledR}$ infrared analyzer estimated the milk-fat content. Milk was standardized at $35 \mathrm{~g}$ fat $/ \mathrm{kg}$ milk according to the Gravert (1987) equation. The result was multiplied by ten to convert the percentage to $\mathrm{g} / \mathrm{kg}$ :

$$
\mathrm{FCM}(3.5 \%)=0.4337 * \mathrm{MY}+16.218 * \mathrm{FY}
$$

In which: $\mathrm{FCM}=$ fat-corrected milk; $\mathrm{MY}=$ milk yield $(\mathrm{kg} /$ day $), \mathrm{FY}=$ fat yield $(\mathrm{kg} /$ day $)$.

The lactation curve was analyzed from fat-corrected milk yield using PROC NLIN of SAS (version 9.1) according to Wood's nonlinear model (Wood, 1967):

$$
\mathrm{y}(\mathrm{t})=\mathrm{at} \mathrm{t}^{\mathrm{b}} * \mathrm{e}^{-\mathrm{ct}}
$$

In which: $\mathrm{y}=$ fat-corrected milk yield $(\mathrm{kg})$, at time $\mathrm{t}$ (days in milk); $\mathrm{a}=$ initial milk yield $(\mathrm{kg}) ; \mathrm{b}=$ increasing production rate before peak lactation; $\mathrm{c}=$ declining production rate after peak lactation; $\mathrm{e}=$ exponential.

From Wood's model, the following parameters were determined: day of peak lactation occurrence $\left(\mathrm{t}_{\mathrm{m}}\right)$, milk yield in peak lactation $\left(\mathrm{y}_{\mathrm{m}}\right)$ and maintenance of peak

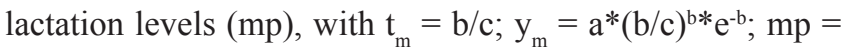
$-(b+1) * \ln c$.

Total milk yield was evaluated during the first 180 days in milk. The coefficient of lactation persistence (lp) was estimated based on milk yield variation after peak lactation according to Rodrigues et al. (2006):

$$
\mathrm{lp}=\mathrm{An} /(\mathrm{A}(\mathrm{n}-1))
$$

In which: $\mathrm{An}=$ monthly average milk yield; $\mathrm{A}(\mathrm{n}-1)=$ previous month average milk yield.

An estimated total milk yield at 305 days in milk was obtained using the parameters of the lactation curve. To detect treatment effects on body weight variation, goats were weighed after calving and weekly throughout lactation.

The effects of dietary energy levels on the parameters of Wood's lactation curve, milk yield and body weight were evaluated using linear and quadratic regressions. Pearson's correlation coefficients between lactation curve variables were also evaluated. Both analyses were performed using SPSS (Version 18).

To evaluate the dry matter intake (DMI) and feed efficiencies ( $\mathrm{kg}$ milk/kg DMI) during lactation, the statistical 
models consider the effects of the calving type, the age of goat, days in milk, and dietary energy levels, as well as interactions among these variables, using PROC MIXED in SAS (Statistical Analysis System, version 9.1). The goat effect inside the energy levels was considered in the model for the appropriate calculation of the residues.

To evaluate the economic impact of the different treatment groups, DMI and production data from 180 days lactation were combined with milk and feed market values quoted in Paraná State, Brazil, in December of 2011 (Table 2). The capital invested in animal feed was considered, by multiplying the diet price by the organic matter intake. The capital generated from milk sales revenue was calculated by multiplying the producer milk price (US\$0.60/L) by the milk yield.

From these data, we calculated the gross margin and cost-benefit ratio using the formulae reported by Antunes and Ries (1998):

Gross margin $=$ generated capital - invested capital Cost-benefit ratio $=$ generated capital/invested capital

Table 2 - Feed and diet unit prices quoted in Paraná State, Brazil, in December 2011

\begin{tabular}{|c|c|c|c|c|c|}
\hline \multirow{2}{*}{ Item } & \multirow{2}{*}{$\begin{array}{l}\text { US\$ } / \mathrm{kg} \\
\text { as feed }\end{array}$} & \multicolumn{4}{|c|}{ Diets $^{1}(\mathrm{US} \$ / 100 \mathrm{~kg}$ as fed) } \\
\hline & & 2.6 & 2.7 & 2.8 & 2.9 \\
\hline Corn silage & 0.07 & 5.72 & 5.84 & 5.84 & 5.85 \\
\hline Ground corn & 0.23 & 2.48 & 1.84 & 1.53 & 1.22 \\
\hline Soybean meal & 0.30 & 2.33 & 2.36 & 2.43 & 2.51 \\
\hline Lactoplus $^{\circledR 2}$ & 1.63 & - & 1.91 & 3.63 & 5.36 \\
\hline Limestone & 1.34 & - & 0.05 & 0.07 & 0.09 \\
\hline Dicalcium phosphate & 0.12 & 0.01 & - & - & - \\
\hline Mineral and vitamin supplement & 0.85 & 0.23 & 0.16 & 0.16 & 0.16 \\
\hline Total & & 10.77 & 12.16 & 13.66 & 15.19 \\
\hline
\end{tabular}

${ }^{1}$ Mcal ME/kg DM.

${ }^{2}$ Calcium salts of fatty acids.

\section{Results}

The dietary treatments had no effect on the length of pregnancy, which ranged from 150 to 157 days, or on the birth weight of the Saanen kids $(3.695 \pm 0.570 \mathrm{~kg})$.

Treatments did not affect body weight (BW) and BW variation for different intervals (Figure 1; Table 3).

The average post-calving $\mathrm{BW}$ was $70.25 \mathrm{~kg}$ and dropped to $65.22 \mathrm{~kg}$ by the end of the first week of lactation, resulting in $7 \% \mathrm{BW}$ loss at a rate of $71.76 \mathrm{~g}$ /day during this time period. The lowest BW values (average $62.00 \mathrm{~kg}$ ) were observed at 90 days in milk, showing only $5 \%$ BW loss compared with the first week of lactation.

Goats fed higher dietary energy levels had higher dry matter intake (DMI), although this difference was most evident after 60 days in milk (Figure 2). The highest DMI $(2.12 \mathrm{~kg} /$ day $)$ was observed with diets containing $2.8 \mathrm{Mcal}$ $\mathrm{ME} / \mathrm{kg} \mathrm{DM}$ and occurred between 97 and 117 days in milk.

By adjusting DMI according to body weight (Figure 3), the level of DMI $(\mathrm{g} / \mathrm{kg} \mathrm{BW})$ was the same among the four diet treatment groups during the period of weight loss, with differences observed only after 90 days in milk.

The largest feed efficiency (FE) values were observed postpartum, with an average of $2.5 \mathrm{~kg}$ milk/kg DMI for all diets. After 90 days in milk, the differences in FE intensified, with a 30\% higher FE calculated for goats fed CSFA diets compared with the control diet (Figure 4).

Even with different dietary energy levels at the last weeks of pregnancy, there was no effect on initial milk yield (a) (Table 4), or on total mammary secretions during the first 24 hours postpartum $(4.45 \pm 1.73 \mathrm{~kg})$.

No difference was observed among treatment groups for either the increasing production rate before peak lactation

Table 3 - Body weight during lactation of Saanen goats fed increasing dietary energy levels

\begin{tabular}{|c|c|c|c|c|c|c|}
\hline \multirow{2}{*}{ Period } & \multicolumn{4}{|c|}{ Diets (Mcal ME/kg DM) } & \multirow{2}{*}{ Regression equations; $\mathrm{R}^{2}$} & \multirow{2}{*}{$\mathrm{SE}$} \\
\hline & 2.6 & 2.7 & 2.8 & 2.9 & & \\
\hline \multicolumn{7}{|c|}{ Body weight (kg) } \\
\hline $1 \mathrm{DIM}$ & 69.98 & 71.26 & 69.10 & 70.64 & $\mathrm{Y}=70.25 ; \mathrm{ns}$ & 2.00 \\
\hline 7 DIM & 64.35 & 65.22 & 66.25 & 65.07 & $\mathrm{Y}=65.22 ; \mathrm{ns}$ & 2.02 \\
\hline 14 DIM & 63.35 & 64.10 & 63.87 & 64.15 & $\mathrm{Y}=63.87 ; \mathrm{ns}$ & 2.06 \\
\hline $21 \mathrm{DIM}$ & 62.48 & 63.38 & 64.59 & 63.68 & $\mathrm{Y}=63.53 ; \mathrm{ns}$ & 2.21 \\
\hline 60 DIM & 64.11 & 64.13 & 65.11 & 63.43 & $\mathrm{Y}=64.20 ; \mathrm{ns}$ & 2.30 \\
\hline 90 DIM & 62.49 & 62.31 & 61.38 & 62.17 & $\mathrm{Y}=62.00 ; \mathrm{ns}$ & 2.40 \\
\hline 180 DIM & 65.96 & 64.49 & 64.75 & 66.34 & $\mathrm{Y}=65.38 ; \mathrm{ns}$ & 2.57 \\
\hline \multicolumn{7}{|c|}{ Changes in body weight (g/day) } \\
\hline 1 to 7 DIM & -80.49 & -86.29 & -40.69 & -79.55 & $\mathrm{Y}=-71.76 ; \mathrm{ns}$ & 10.32 \\
\hline 7 to 14 DIM & -14.16 & -16.04 & -34.04 & -13.14 & $\mathrm{Y}=-19.35 ; \mathrm{ns}$ & 3.43 \\
\hline 14 to 21 DIM & -12.45 & -10.24 & 10.28 & -6.69 & $\mathrm{Y}=-4.78 ; \mathrm{ns}$ & 3.59 \\
\hline 21 to 60 DIM & 4.18 & 1.93 & 1.34 & -0.65 & $\mathrm{Y}=1.70 ; \mathrm{ns}$ & 1.34 \\
\hline 60 to 90 DIM & -5.39 & -6.06 & -12.44 & -4.20 & $\mathrm{Y}=-7.02 ; \mathrm{ns}$ & 2.16 \\
\hline 90 to 180 DIM & 3.85 & 2.42 & 3.74 & 4.63 & $\mathrm{Y}=3.66 ; \mathrm{ns}$ & 1.00 \\
\hline
\end{tabular}

DIM - days in milk; $n s-P>0.05 ; \mathrm{R}^{2}$ - coefficient of determination; $\mathrm{SE}$ - standard error. 
(b) or for the declining production rate after peak lactation (c). However, there was a quadratic effect on the day of peak lactation, with a late peak (49 days in milk) observed for dams receiving $2.78 \mathrm{Mcal} \mathrm{ME} / \mathrm{kg} \mathrm{DM}$ diets.

In this study, increasing dietary energy levels had a quadratic effect on the maintenance of peak lactation levels, with the maximum point (6.69) observed for goats receiving a $2.78 \mathrm{Mcal} \mathrm{ME} / \mathrm{kg} \mathrm{DM}$ diet (Table 4).

Changes in the shape of the lactation curve (Figure 5) were reflected in the total milk yield. A quadratic effect was observed for total milk yields at 180 days in milk and for estimated total milk yields at 305 days in milk, with the maximum yields obtained with the $2.85 \mathrm{Mcal} \mathrm{ME} / \mathrm{kg} \mathrm{DM}$ $(648.80 \mathrm{~kg})$ and $2.82 \mathrm{Mcal}$ ME $/ \mathrm{kg}$ DM $(980.55 \mathrm{~kg})$ diets, respectively (Table 4$)$. These values are close to the diet with the highest DMI (2.8 Mcal ME/kg DM).

Until 180 days in milk, goats fed diet with lower CSFA levels (2.7 Mcal ME/kg DM) yielded $147.5 \mathrm{~kg}$ more milk than those fed the control diet (2.6 Mcal ME/kg DM), equivalent to a $31 \%$ increase.

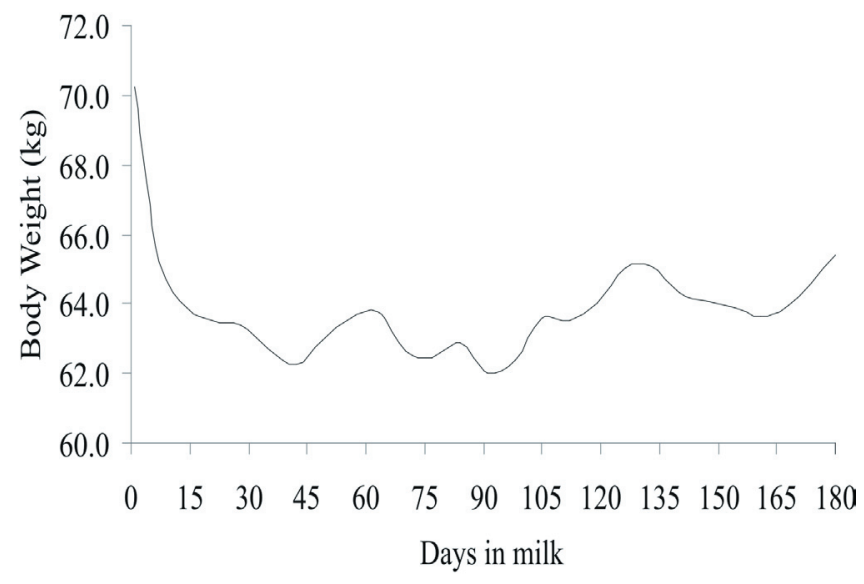

Figure 1 - Body weight of Saanen goats during lactation.

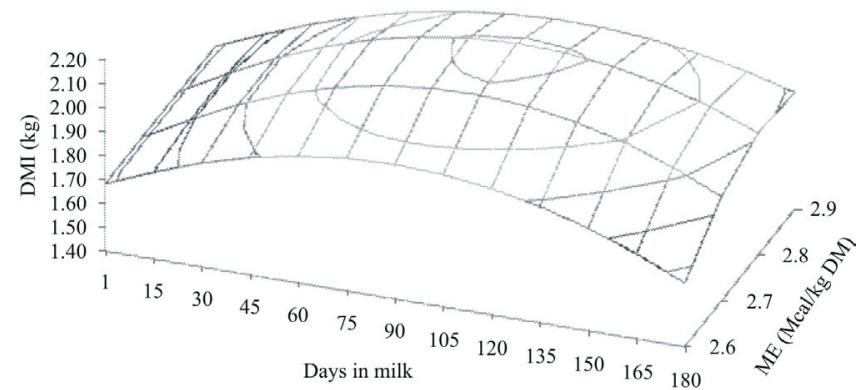

$\mathrm{Y}=1.675-0.704 * \mathrm{DIM}+0.003 * \mathrm{DIM}^{2}+0.518 * \mathrm{DIM}^{*} \mathrm{ME}-0.094 * \mathrm{DIM}^{*} \mathrm{ME}^{2}-$ $0.002 * \mathrm{DIM}^{2} * \mathrm{ME}+0.0004 \mathrm{DIM}^{2} * \mathrm{ME}^{2} ; \mathrm{R}^{2}=0.25$

$\mathrm{DIM}=$ days in milk; $\mathrm{ME}=$ metabolizable energy of diet.

Figure 2 - Dry matter intake (DMI) in $\mathrm{kg}$ during lactation of Saanen goats fed increasing dietary energy levels.
Milk yields at 180 days in milk were correlated with initial milk yield and milk yield in peak lactation. Estimated milk yields at 305 days in milk was correlated with milk yield at peak lactation; declining production rate after peak lactation; and coefficient of lactation persistence (Table 5).

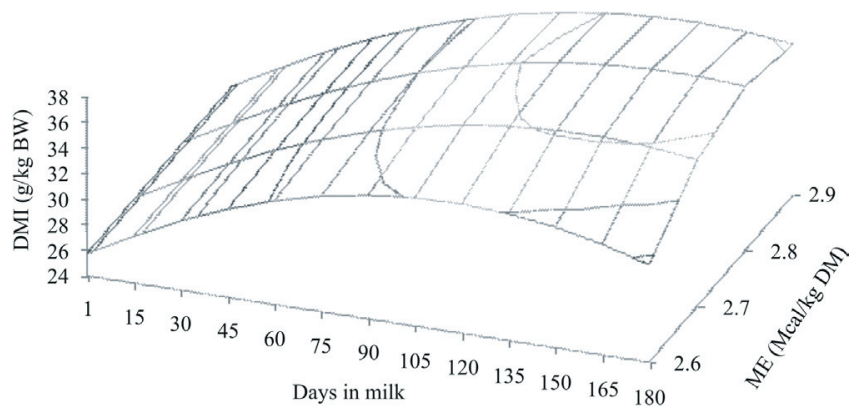

$\mathrm{Y}=25.605+0.147 * \mathrm{DIM}-0.030 * \mathrm{DIM}^{2}+0.021 * \mathrm{DIM}^{2} * \mathrm{ME}-0.004 * \mathrm{DIM}^{2} * \mathrm{ME}^{2} ; \mathrm{R}^{2}=0.21$ $\mathrm{DIM}=$ days in milk; $\mathrm{ME}=$ metabolizable energy of diet.

Figure 3 - Dry matter intake (DMI) in $\mathrm{g} / \mathrm{kg}$ of body weight (BW) during lactation of Saanen goats fed increasing dietary energy levels.

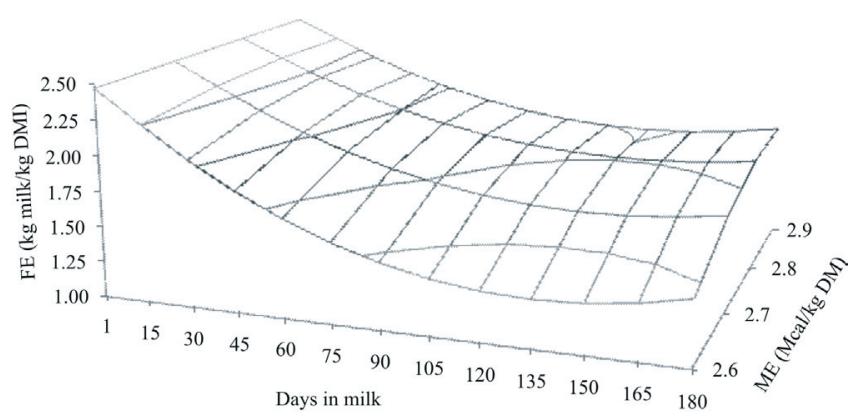

$\mathrm{Y}=2.495-1.069 * \mathrm{DIM}+0.005 * \mathrm{DIM}^{2}+0.750 * \mathrm{DIM}^{*} \mathrm{ME}-0.003 * \mathrm{DIM}^{2} * \mathrm{ME}-$ $0.133 * \mathrm{DIM}^{*} \mathrm{ME}^{2}+0.0006 * \mathrm{DIM}^{2} * \mathrm{ME}^{2} ; \mathrm{R}^{2}=0.62$ $\mathrm{DIM}=$ days in milk; $\mathrm{ME}=$ metabolizable energy of diet.

Figure 4 - Feed efficiencies (FE) during lactation of Saanen goats fed increasing dietary energy levels.

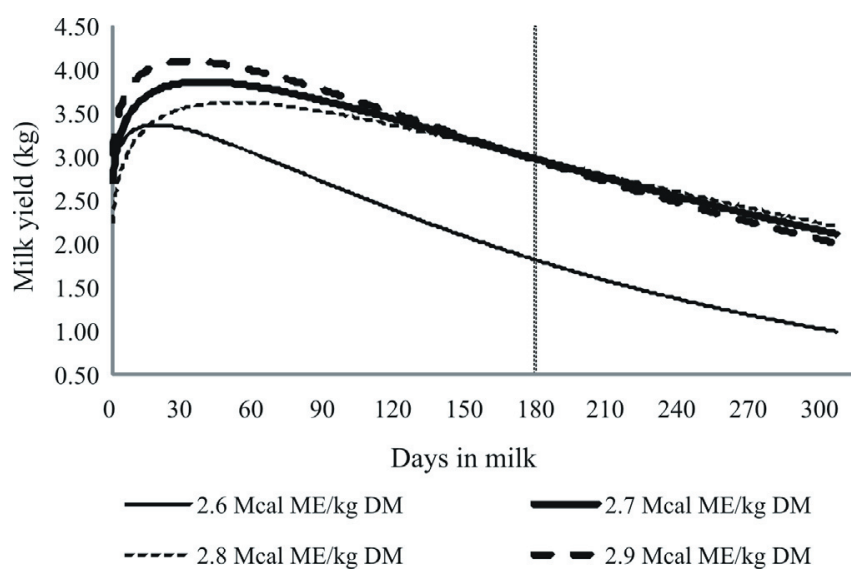

Figure 5 - Lactation curve of Saanen goats fed increasing dietary energy levels. 
Table 4 - Parameters of Wood's lactation curve of Saanen goats fed increasing dietary energy levels

\begin{tabular}{|c|c|c|c|c|c|c|}
\hline \multirow{2}{*}{ Variable } & \multicolumn{4}{|c|}{ Diets (Mcal ME/kg DM) } & \multirow{2}{*}{ Regression equations; $\mathrm{R}^{2}$} & \multirow{2}{*}{ SE } \\
\hline & 2.6 & 2.7 & 2.8 & 2.9 & & \\
\hline $\mathrm{a}$ & 2.750 & 2.723 & 2.239 & 3.041 & $\mathrm{Y}=2.718 ; \mathrm{ns}$ & 0.14 \\
\hline $\mathrm{b}$ & 0.103 & 0.131 & 0.163 & 0.119 & $\mathrm{Y}=0.127 ; \mathrm{ns}$ & 0.01 \\
\hline $\mathrm{c}$ & 0.005 & 0.003 & 0.003 & 0.004 & $\mathrm{Y}=0.004 ; \mathrm{ns}$ & 0.0005 \\
\hline$t_{\mathrm{m}}$ & 19 & 39 & 53 & 34 & $\mathrm{Y}=-7287.43+5275.82 X-948.52 \mathrm{X}^{2} ; 0.74$ & 3.57 \\
\hline$y_{m}$ & 3.335 & 3.805 & 3.609 & 4.101 & $\mathrm{Y}=3.719 ; \mathrm{ns}$ & 0.14 \\
\hline $\begin{array}{ll}\mathrm{m} \\
\mathrm{mp}\end{array}$ & 5.90 & 6.51 & 6.71 & 6.32 & $Y=-184.02+137.24 X-24.69 X^{2} ; 0.53$ & 0.11 \\
\hline lp & 0.88 & 0.93 & 0.94 & 0.92 & $\mathrm{Y}=0.92 ; \mathrm{ns}$ & 0.01 \\
\hline MY180 & 475.52 & 623.03 & 599.15 & 652.89 & $Y=-20578.28+14900.01 X-2614.74 X^{2} ; 0.46$ & 25.45 \\
\hline MY305 & 653.70 & 935.65 & 913.96 & 956.07 & $Y=-49896.28+36076.84 X-6395.54 X^{2} ; 0.53$ & 43.89 \\
\hline
\end{tabular}

$\mathrm{a}$ - initial milk yield $(\mathrm{kg})$; b - increasing production rate before peak lactation; $\mathrm{c}$ - declining production rate after peak lactation; $\mathrm{t}_{\mathrm{m}}$ - day of peak lactation occurrence; $\mathrm{y}_{\mathrm{m}}$ - milk yield in peak lactation; mp - maintenance of peak lactation levels; lp - coefficient of lactation persistence; MY180 - milk yields at 180 days in milk; MY305 - estimated milk yields at 305 days in milk.

$\mathrm{R}^{2}$ - coefficient of determination; $\mathrm{SE}$ - standard error; $\mathrm{ns}-\mathrm{P}>0.05$.

Table 5 - Pearson correlation among parameters of Wood's lactation curve of Saanen goats fed increasing dietary energy levels

\begin{tabular}{|c|c|c|c|c|c|c|c|c|}
\hline Variable & $\mathrm{b}$ & $\mathrm{c}$ & $\mathrm{t}_{\mathrm{m}}$ & $\mathrm{y}_{\mathrm{m}}$ & $\mathrm{mp}$ & $\mathrm{lp}$ & MY180 & MY305 \\
\hline b & & $+0.52 *$ & +0.47 & +0.03 & +0.06 & -0.38 & -0.04 & -0.13 \\
\hline $\mathrm{c}$ & & & -0.45 & +0.01 & $-0.80 * *$ & $-0.99 * *$ & -0.42 & $-0.64 * *$ \\
\hline $\mathrm{y}_{\mathrm{m}}$ & & & & & -0.13 & -0.01 & $+0.89 * *$ & $+0.72 * *$ \\
\hline $\mathrm{mp}$ & & & & & & $+0.88 * *$ & +0.32 & $+0.56^{*}$ \\
\hline $1 \mathrm{p}$ & & & & & & & +0.44 & $+0.67 * *$ \\
\hline
\end{tabular}

a - initial milk yield $(\mathrm{kg})$; $\mathrm{b}$ - increasing production rate before peak lactation; $\mathrm{c}$ - declining production rate after peak lactation; $\mathrm{t}_{\mathrm{m}}$ - day of peak lactation occurrence; $\mathrm{y}_{\mathrm{m}}$ - milk yield in peak lactation; $\mathrm{mp}$ - maintenance of peak lactation levels; lp - coefficient of lactation persistence.

MY180 - milk yields at 180 days at milk; MY305 - estimated milk yields at 305 days in milk; * $(\mathrm{P}<0.05) ; * *(\mathrm{P}<0.01)$.

Table 6 - Economic results of diets with increasing energy levels during lactation of Saanen goats

\begin{tabular}{lcccc}
\hline \multirow{2}{*}{ Variable $^{1}$} & \multicolumn{4}{c}{ Diets (Mcal ME/kg DM) } \\
\cline { 2 - 5 } & 2.6 & 2.7 & 2.8 & 2.9 \\
\hline Milk yield (kg/day) $_{\text {Milk sales revenue (US\$/day) }}$ & 2.64 & 3.46 & 3.33 & 3.63 \\
Organic matter intake (kg/day) & 5.21 & 2.08 & 2.00 & 2.18 \\
Feed cost (US\$/day) & 0.56 & 0.64 & 5.06 & 5.27 \\
Gross margin (US\$/day) & 1.02 & 1.43 & 1.31 & 0.80 \\
Cost-benefit ratio (US\$/US\$) & 2.82 & 3.23 & 2.89 & 2.72 \\
\hline
\end{tabular}

${ }^{1}$ Per goat.

Despite obtaining the best milk production from dams fed diets containing approximately $2.8 \mathrm{Mcal} \mathrm{ME} / \mathrm{kg} \mathrm{DM}$, better economic results were observed for diets containing 2.7 Mcal ME/kg DM (Table 6). Each US\$1.00 invested in feed had a gain of US\$3.23 from milk sales and a gross margin of US\$1.43/day.

\section{Discussion}

The lowest BW values at 90 days in milk (Table 3; Figure 1) contrast with results reported in the literature (Ribeiro, 1997; Zambom et al., 2005a; Eknæs et al., 2006), which asserts that mobilization of body reserves occurs only until approximately 60 days in milk.
Mobilization of body reserves does not seem to be influenced by diets with energy levels above those recommended by the NRC (2007). This has also been observed in lactating goats fed diets with increased energy levels either by including partially hydrogenated tallow (Brown-Crowder et al., 2001) or by adding an increased amount of concentrate (Zambom et al., 2005a).

Sanz Sampelayo et al. (2002a) reported feed refusal by goats fed concentrate plus CSFA, with a negative impact on DMI. However, this problem was not encountered in the present study, nor was it observed by Teh et al. (1994), who fed higher levels of CSFA ( $90 \mathrm{~g} / \mathrm{kg}$ DM of diet) to goats.

The highest DMI observed between 97 and 117 days in milk (Figure 2) was later than that observed by Zambom et al. (2005a), in which the highest DMI was observed between 56 and 98 days in milk.

The lack of treatment effects on the level of DMI $(\mathrm{g} / \mathrm{kg} \mathrm{BW})$ during the period of weight loss (Figure 3) indicates that there may be an association between dietary CSFA and the metabolic status during negative energy balance.

During the period when the body mobilizes its energy reserves, prolactin stimulates lipid uptake by the mammary glands and reduces lipogenesis in adipose tissue (Palmquist 
and Mattos, 2011). Thus, the CSFA diets may have contributed to the accumulation of circulating fatty acids during early lactation and may stimulate cholecystokinin secretion, which causes the feeling of satiety and regulates energy intake (Palmquist and Mattos, 2011; Silva, 2011).

After this period, the recovery of energy reserves by the accumulation of fatty acids in adipocytes (Chilliard et al., 2003) in association with energy requirements for lactation possibly stimulates a higher DMI for those goats receiving CSFA diets.

According to Eknæs et al. (2006), during negative energy balance, milk yield is maintained by the mobilization of energy reserves stored as body fat. This explains the largest FE values observed in postpartum, when the level of DMI is lower.

Zambom et al. (2005b) also observed higher values for FE in early lactation, with a decrease at 60 days in milk, but with a positive linear effect of increasing dietary energy. Oliveira Jr. et al. (2002) observed that lactating Alpine goats fed soybeans increased their FE by $24 \%$. In both studies, FE values were lower than those observed in the present study, suggesting that CSFA provide a better energy source for lactating goat diets. Teh et al. (1994) explained that the addition of CSFA could increase the density of the diet without reducing the fiber content and digestibility, thus improving the efficiency of energy use.

Furthermore, CSFA supplementation contributes to the incorporation of dietary fatty acids into milk fat, decreasing the demand for acetate and glucose for the de novo synthesis of fatty acids by the mammary glands. Thus, there is an increased availability of glucose for the synthesis of lactose, which, through its osmotic action, increases milk yield (Wu and Huber, 1994; González, 2001).

The lack of treatment effects on initial milk yield (a) or on total mammary secretions during the first 24 hours postpartum may be explained by the fact that the goats were at the limit of their milk yield efficiency due to the mobilization of their energy reserves (Eknæs et al., 2006).

The level of initial milk yield $(2.72 \mathrm{~kg})$ and the yield during peak lactation $(3.72 \mathrm{~kg})$ were higher than those described for Saanen goats in Brazil by Macedo et al. (2001) and Zambom et al. (2005a).

The observed quadratic effect on peak lactation day is beneficial because it is associated with greater milk yield (Zambom et al., 2005a). Delayed peak lactation is related to a longer period of mammary development, during which secretory cells increase in number and secretory capacity (Capuco et al., 2003). Thus, the observed effect on peak lactation day is reflected in the longer maintenance of peak lactation production levels, as demonstrated by comparing milk yields at 180 days in milk and estimated milk yields at 305 days in milk (Table 4), both of which are positively correlated (Table 5).

The maintenance of peak lactation levels can be expressed as a non-dimensional measure of the time interval during which milk yield is maintained at a value similar to the peak (Macciotta et al., 2008). According to Capuco et al. (2003), increased lactation persistence has many benefits for the producer, including promoting a more efficient lactation period and diluting the production costs.

The differences in the shapes of the lactation curves (Figure 5) were attributed to delayed peak lactation and lengthened persistence of peak lactation, which was observed for CSFA diets. At 180 days in milk, the goats receiving CSFA produced nearly $3.0 \mathrm{~kg}$ of milk/day versus $2.0 \mathrm{~kg} /$ day for the control diet. These results contradict Sanz Sampelayo et al. (2002b), who observed no effect on milk yield in CSFA-supplemented animals, and differ from Hosam (2011), who showed that milk yield increased only with diets containing the highest CSFA levels.

Lactation curves for goats fed CSFA were similar without showing effects on the coefficient of lactation persistence. The average coefficient of lactation persistence was higher than that recommended by Ribeiro (1997) for dairy goats $(0.90)$. The coefficient of lactation persistence has a negative correlation (-0.99), with a declining production rate after peak lactation (c) (Table 5), which is influenced by the number and activity of the mammary secretory cells (Knight and Peaker, 1984).

The economic evaluation corroborates results from Menezes (2008), who concluded that maximum productivity does not always equate with maximum economic productivity. The better results observed with a lower level of dietary CSFA indicate that the strategic use of supplementation could reduce feed cost, which was 15 to $43 \%$ higher than the control diet.

\section{Conclusions}

Increasing the dietary energy level of Saanen goats using calcium salts of fatty acids changes their lactation curves, resulting in the best milk production response with $2.85 \mathrm{Mcal} \mathrm{ME} / \mathrm{kg} \mathrm{DM}$ diets and the best economic results with $2.7 \mathrm{Mcal} \mathrm{ME} / \mathrm{kg}$ DM diets.

\section{References}

Antunes, L. M. and Ries, L. R. 1998. Gerência agropecuária: análise de resultados. Agropecuária, Guaíba.

Brown-Crowder, I. E.; Hart, S. P.; Cameron, M.; Sahlu, T. and Goetsch, A. L. 2001. Effects of dietary tallow level on performance of Alpine does in early lactation. Small Ruminant Research 39:233-241. 
Capuco, A. V.; Ellis, S. E.; Hale, S. A.; Long, E.; Erdman, R. A.; Zhao, X. and Paape, M. J. 2003. Lactation persistency: Insights from mammary cell proliferation studies. Journal of Animal Science 81:18-31.

Chilliard, Y.; Ferlay, A.; Rouel, J. and Lamberet, G. 2003. A review of nutritional and physiological factors affecting goat milk lipid synthesis and lipolysis. Journal of Dairy Science 86:1751-1770.

Eknæs, M.; Kolstad, K.; Volden, H. and Hove, K. 2006. Changes in body reserves and milk quality throughout lactation in dairy goats. Small Ruminant Research 63:1-11.

González, F. H. D. 2001. Composição bioquímica do leite e hormônios da lactação. p.5-22. In: Uso do leite para monitorar a nutrição e o metabolismo de vacas leiteiras. González, F. H. D.; Durr, J. W. Fontaneli, R. S., eds. Porto Alegre.

Gravert, H. O. 1987. Dairy cattle production. Elsevier Science, Nova York.

Hosam, T. 2011. Effects of varying levels of protected fat on performance of Shami goats during early and mid lactation. Turkish Journal of Veterinary and Animal Sciences 35:67-74.

Knight, C. H. and Peaker, M. 1984. Mammary development and regression during lactation in goats in relation to milk secretion. Quarterly Journal of Experimental Physiology 69:331-338.

Macciotta, N. P. P.; Dimauro, C.; Steri, R. and Cappio-Borlino, A. 2008. Mathematical modeling of goat lactation curves. p.31-46. In: Dairy goats feeding and nutrition. Cannas, A.; Pulina, G., eds. CAB International, Oxfordshire.

Macedo, V. P.; Damasceno, J. C.; Santos, G. T.; Martins, E. N. and Macedo, F. A. F. 2001. Comportamento da curva de lactação de cabras mestiças Saanen em função da suplementação de concentrado e do sistema de produção. Revista Brasileira Zootecnia 30:2093-2098.

Menezes, G. R. O. 2008. Avaliação da produção de leite em cabras da raça Saanen utilizando modelos de regressão aleatória. Dissertação (M.Sc.). Universidade Federal de Viçosa, Viçosa, MG, Brasil.

NRC - National Research Council. 2007. Nutrient requirements of small ruminants. National Academy Press, Washington, D.C.

Oliveira Jr., R. C.; Susin, I.; Pires, A. V.; Simas, J. M. C. and Morais, J. B. 2002. Desempenho de cabras em lactação com grão de soja. Acta Scientiarum 24:1113-1118.
Palmquist, D. L. and Mattos, W. R. S. 2011. Metabolismo de lipídeos. p.299-322. In: Nutrição de ruminantes. 2.ed. Berchielli, T. T.; Pires, A.V. and Oliveira, S. G., eds. Jaboticabal: Funep.

Ribeiro, S. D. A. 1997. Caprinocultura: criação racional de caprinos. Nobel, São Paulo.

Rodrigues, L.; Spina, J. R.; Teixeira, I. A. M. A.; Dias, A. C.; Sanches, A. and Resende, K. T. 2006. Produção, composição do leite e exigências nutricionais de cabras Saanen em diferentes ordens de lactação. Acta Scientiarum. Animal Sciences 28:447-452.

Sanz Sampelayo, M. R.; Pérez, L.; Alonso, J. J. M.; Extremera, F. G.; and Boza, J. 2002a. Effects of concentrates with different contents of protected fat rich in PUFAs on the performance of lactating Granadina goats. 1. Feed intake, nutrient digestibility, $\mathrm{N}$ and energy utilization for milk production. Small Ruminant Research 43:133-139.

Sanz Sampelayo, M. R.; Pérez, L.; Alonso, J. J. M.; Amigo, L.; and Boza, J. 2002b. Effects of concentrates with different contents of protected fat rich in PUFAs on the performance of lactating Granadina goats. 2. Milk production and composition. Small Ruminant Research 43:141-148.

Silva, J. F. C. 2011. Mecanismos reguladores de consumo. p.61-82. In: Nutrição de ruminantes. 2.ed. Berchielli, T. T.; Pires, A. V. and Oliveira, S. G., eds. Funep, Jaboticabal.

Teh, T. H.; Trung, L. T.; Jia, Z. H.; Gipson, T. A.; Ogden, K. B. and Sweeney, T. F. 1994. Varying amounts of rumen-inert fat for high producing goats in early lactation. Journal of Dairy Science 77:253-258.

Wood, P. D. P. 1967. Algebraic model of the lactation curve in cattle. Nature 216:164-165.

Wu, Z. and Huber, J.T. 1994. Relationship between dietary fat supplementation and milk protein concentration in lactating cows: A review. Livestock Production Science 39:141-155.

Zambom, M. A.; Alcalde, C. R.; Martins, E. N.; Santos, G. T.; Macedo, F. A. F.; Horst, J. A. and Veiga, D. R. 2005a. Curva de lactação e qualidade do leite de cabras Saanen recebendo rações com diferentes relações volumoso: concentrado. Revista Brasileira de Zootecnia 34:2515-2521.

Zambom, M. A.; Alcalde, C. R.; Silva, K. T.; Macedo, F. A. F.; Santos, G. T.; Borghi, E. L. and Barbosa, E. D. 2005b. Ingestão, digestibilidade das rações e produção de leite em cabras Saanen submetidas a diferentes relações volumoso:concentrado na ração. Revista Brasileira de Zootecnia 34:2505-2514. 